\title{
INCORPORATING SUSTAINABILITY INTO SMALL BUSINESS INNOVATION
}

\author{
ESTI DWI RINAWIYANTI \\ Industrial Engineering Department, Engineering Faculty \\ University of Surabaya, Surabaya \\ Indonesia \\ estidwi@staff.ubaya.ac.id
}

\begin{abstract}
To win the increasingly fierce competition, small and medium micro enterprises (SMEs) are required to consistently innovate. However, when performing innovation, they should not only give priorities to profit, but also have awareness to human and the environment. This is appropriate with the triple bottom line principles of sustainable development, i.e. financial, social, and environmental. This research was conducted with purposes to describe how SMEs in Indonesia incorporate sustainability into their business innovation; to recognize internal and external factors which trigger sustainable innovation and also to identify the obstacles faced by SMEs in implementing it. The case study was taken from food processing SMEs in Surabaya as one of the prioritized industries in East Java. The survey method was used to get primary data from 100 respondents through questionnaire. Based on the results it can be recognized internal trigger factors of sustainable innovation among SMEs, i.e product (product remains favored, quality improvement, and product uniqueness), profit, business owner, and competitive advantage; while external trigger factors are consumers, competitors, government, and other parties. Internal obstacles of SMEs in sustainable innovation implementation are lack of human resource, time and money restriction, and the reluctance to perform innovation; whereas external obstacles are lack of information and lack of government support.
\end{abstract}

Keywords: Sustainable Innovation, Trigger Factors, Obstacles, SMEs

\section{INTRODUCTION}

Small and Medium Business which is familiar with Small and Medium Enterprises (SMEs) has an important role in the economy of a country, even in Indonesia. Currently, SMEs can be regarded as the backbone of Indonesia's economy which contributed 57\% to the Gross Domestic Product of Indonesia and also absorbed up to 97\% workers (Politik Indonesia, 2013). In 2013 there were 6.8 million SMEs in East Java, which rose 2 million in number from 2012, so that the Gross Domestic Product (GDP) of East Java reached Rp. 1,012 trillion. (Suara Surabaya, 2013). In order to survive and to deal with competitors, SMEs need to innovate continuously. Innovation is a key to the growth of SMEs as it provides firms with a competitive edge over other firms in the industry.

Generally SMEs have classic barriers related to unskilled human resources, management skills inadequacy, and lack of financial access and market, as well as information and technology constraints (Hardono, 2006). Furthermore, in performing their business, SMEs get less publicity and a little support from the community and the media spotlight, which makes them less aware of environmental issues. As a result, SMEs tend to be indifferent to the implementation of environmentally friendly practices, which usually requires more capital and public inspection. SMEs are likely reluctance to implement sustainability because it does not seem to affect the company's financial performance significantly (Prabawani, 2013). Nevertheless, because of their lack of knowledge and lack of an understanding of the environmental impacts and the limited use of the updated technology production, activities of SMEs contribute high enough to pollute the environment (Indonews, 2014). Moreover, the environmental management is often considered burdensome by the SMEs, so that it is not managed properly. One result of misproper environmental handling is a pollution which can cause social conflict and give an impact on the 